\title{
"Perception About Causes And Impact Of Poor Leadership (A Study In Sargodha City)"
}

\author{
Ayesha Tehreem, Dr. Yasir Nawaz, Dr. BabakMahmood, \\ Malik Muhammad Sohail, Abeeda Haroon \\ Scholar, Department of Sociology, University of Sargodha, Sargodha, Pakistan. \\ Assistant Professor, Department of Sociology, University of Sargodha, Sargodha, Pakistan. \\ Assistant Professor, Department of Sociology, University of Sargodha, Sargodha, Pakistan. \\ Visiting Lecturer, Department of Humanities and Social Sciences, National Textile University, Faisalabad, \\ Pakistan. \\ Research Officer, Punjab Assembly, Punjab, Pakistan.
}

\begin{abstract}
The prime objective of the research was to know the people's perception about poor leadership. Several variables like age, education, gender and some intervening variables like, Information, Education, Knowledge and Ethnicity were also analyzed in search of the study objectives. The review of literature provided a framework for understanding this body of knowledge. The sample size of present research was 150 respondents. A stratified random sampling design was used for the selection of respondents. The questionnaire instrument was used to collect data and Pre-testing was carried out. The collected data was analyzed by using Statistical Package of Social Sciences (SPSS). The finding shows that several independent and intervening variables effect on behavior of leader and respondents were strongly agreed that leader behavior to people is usually complex rather than simple.
\end{abstract}

\section{Introduction}

Leadership is a multifaceted phenomenon, leaders are concerned with the spiritual aspect of their work and they hold a hidden power in organizations (Squires, 2001). There was a time when people were at peace happy and satisfied there was hardly any need for leadership. On the other hand when the human conditions are at risk and the situation urges someone to step forward and initiate change, there is a need for leadership. In addition to this leaders have a vision of the future and they develop strategies that are necessary to bring about changes needed to achieve that vision (English, 1992). Hersey and Blanchard (1969) claim that leadership is a broader concept. Leadership involves working with people to accomplish goals.

Throughout history theoretical explanations for leadership have been offered. The Trait Approach up at 1950s claimed that leadership ability is natural (Bryman, 1993). Leadership traits include ambition and energy, honesty and integrity, desire to lead, knowledge and self confidence. People become leaders for the traits that they own such as brainpower, appearance, language ability, etc. (Bolman et al., 1994). In the late 1960s, the Behavioral Approach became popular that great leadership is based on what someone does and effectiveness in leadership has to do with how a leader behaves. The Contingency Approach became popular in the late 1960s to the early 1980s suggests that effective leadership is dependent upon the situation. It recommends that a particular style is suitable in one condition but perform poor in a different circumstances. In the late 1970's the concepts of transactional and transformational leadership emerged. Transformational leadership behaviors include individualized consideration, intellectual stimulation, and inspirational motivation and idealized influence attributes or idealized influence Behavior (Morakul, 2001; Jansen, 2000).

Poor leadership can affect people lifestyle. One effect of poor leadership on people is that they become lack of direction and lack of purpose. If people understand that the country is under pressure because of poor leadership, the confidence of that people will lower. When some people confidence lowers, other people confidence is clear to pursue. People sense when their leadership is making poor decisions, making it difficult for people to carry on a helpful attitude. When the people understand that a country is under poor leadership, they start on to disbelief the leaders and any decisions they make. Countries run by poor leaders can't maintain high-performing people. Being in a leadership role requires a person to have efficient communication skills. Whether you are a leader in having practical communication skills is important as it gives you authority and makes your directions easier to people. Develop your communication skills to increase belief from the people you lead as well. Failure, lack of skill, lack of ability or carelessness by leaders can result in lack of focus; fail ethical, decreased efficiency and member yield.

Various outcomes to a leader might influence not only how that leader is apparent but also the degree of persuade that leader might consequently obtain (Stefani et al., 1999). On the basis of current charismatic 
leadership theories, it was predictable that leaders who appeared willing to tolerate suffering for the appearance of their beliefs would be supposed differently than leaders who appeared to benefit in some way. The relationship between influence and consequent leader influence was established. Sacrificing resulted in greater power, whereas benefiting reduced it. This relationship was mediated by attributions made about leader intentions. The relationship between influence and consequent was also mediated by perceptions of charisma.

When leadership fails and a command climate break down, sad things can happen. This is the research of failed leadership and a command climate which had collapse into an unhealthy state of lack of concern and nonfulfillment. Failed leadership can have disastrous consequences. "Leaders make a difference, large and complex organizations make special demands on the men and women who run them (Anthony, 1995)."

\section{Objectives:}

To find out the perception of people about poor leadership.

Table 1: Percentage distribution along with mean and standard deviation regarding Leader motivate and solve problem of people.

\begin{tabular}{|c|c|c|c|c|c|c|c|}
\hline \multirow[t]{2}{*}{$\begin{array}{l}\text { Leader motivate and solve } \\
\text { problem of people }\end{array}$} & $\begin{array}{l}\text { Strongly } \\
\text { Agreed }\end{array}$ & Agreed & $\begin{array}{l}\text { Neither } \\
\text { Agreed, Nor } \\
\text { Disagreed }\end{array}$ & Disagreed & $\begin{array}{l}\text { Strongly } \\
\text { Disagreed }\end{array}$ & \multirow[t]{2}{*}{ Mean } & \multirow[t]{2}{*}{ S.D } \\
\hline & \multicolumn{5}{|c|}{ Percentage } & & \\
\hline $\begin{array}{l}\text { Leader creates co-operative } \\
\text { environment with people. }\end{array}$ & 24.7 & 21.3 & 6.7 & 25.3 & 22.0 & 2.99 & 1.533 \\
\hline $\begin{array}{l}\text { The leader is able to include } \\
\text { the views and priorities of the } \\
\text { people. }\end{array}$ & 17.3 & 24.7 & 1.3 & 27.3 & 29.3 & 3.27 & 1.527 \\
\hline $\begin{array}{l}\text { The leader is able to identify } \\
\text { new and creative ways to } \\
\text { solve problems. }\end{array}$ & 16.0 & 16.7 & 7.3 & 32.0 & 28.0 & 3.39 & 1.451 \\
\hline $\begin{array}{l}\text { Leader is capable of creating } \\
\text { an environment where } \\
\text { differences of opinion can be } \\
\text { voiced. }\end{array}$ & 6.0 & 10.7 & 6.7 & 36.7 & 40.0 & 3.94 & 1.200 \\
\hline $\begin{array}{l}\text { Leader takes the } \\
\text { responsibility to make timely } \\
\text { decisions. }\end{array}$ & 34.7 & 34.0 & 5.3 & 10.0 & 16.0 & 2.39 & 1.451 \\
\hline $\begin{array}{l}\text { Leader is capable of } \\
\text { resolving conflicts among } \\
\text { people. }\end{array}$ & 29.3 & 40.0 & 3.3 & 17.3 & 10.0 & 2.39 & 1.335 \\
\hline $\begin{array}{l}\text { Leader has the ability of } \\
\text { combining the perspectives, } \\
\text { resources and skills of } \\
\text { people. }\end{array}$ & 32.0 & 36.0 & 5.3 & 16.0 & 10.7 & 2.37 & 1.359 \\
\hline $\begin{array}{l}\text { Leader is involved in } \\
\text { inspiring or motivating } \\
\text { people to participate in } \\
\text { activities. }\end{array}$ & 31.3 & 45.3 & 7.3 & 8.0 & 8.0 & 2.16 & 1.188 \\
\hline $\begin{array}{llr}\text { Leader is in touch } & \text { with } \\
\text { people } & \text { situations } & \text { and } \\
\text { feelings. } & & \\
\end{array}$ & 33.3 & 38.0 & 2.0 & 19.3 & 7.3 & 2.29 & 1.308 \\
\hline Leader keeps an open mind. & 26.7 & 50.0 & 5.3 & 10.7 & 7.3 & 2.22 & 1.169 \\
\hline $\begin{array}{l}\text { Leader helps others and feels } \\
\text { comfortable in the group. }\end{array}$ & 36.0 & 40.7 & 4.7 & 9.3 & 9.3 & 2.15 & 1.268 \\
\hline
\end{tabular}

Value indicators shows that $24.7 \%$ people were strongly agreed with the statement that Leader creates cooperative environment with people and $21.3 \%$ people were agreed with this, $25.3 \%$ respondents were disagreed with the statement, while only $22.0 \%$ people were strongly disagreed that Leader creates co-operative environment with people, only $6.7 \%$ respondents were neither agreed, nor disagreed. So it shows that majority of people were disagreed that Leader creates co-operative environment with people.Result of data shows that about $17.3 \%$ respondents were strongly agreed that the leader is able to include the views and priorities of the people, $24.7 \%$ people were agreed, and only $1.3 \%$ people are neither agreed, nor disagreed, while $27.3 \%$ were disagreed with statement, $29.3 \%$ respondents were strongly disagreed. Majority $16.0 \%$ of respondents were strongly agreed with statement that the leader is able to identify new and creative ways to solve problems. Data shows that 6.0 percent respondents are strongly agreed that Leader is capable of creating an environment where differences of opinion can be voiced, 10.7 percent were agreed, while $40.0 \%$ respondents were disagreed. It shows that majority of people were strongly disagreed on the statement that Leader is capable of creating an environment where differences of opinion can be voiced.Data reflects that $29.3 \%$ respondents were strongly 
agreed, majority $40.0 \%$ people were agreed with the opinion that Leader is capable of resolving conflicts among people.Data shows that $32.0 \%$ respondents were strongly agreed that Leader has the ability of combining the perspectives, resources and skills of people, while a majority $36.0 \%$ of people were agreed with the statement, $16.0 \%$ people were disagreed with the statement, only $10.7 \%$ respondents were strongly disagreed with this, $5.3 \%$ people were neither agreed, nor disagreed on the statement. It shows that majority of people agreeing on the statement that Leader has the ability of combining the perspectives, resources and skills of people.

Data we gather from respondents shows that $31.3 \%$ respondent were strongly agreed that Leader is involved in inspiring or motivating people to participate in activities., while majority, $45.3 \%$ people were agreed. The findings reflects that majority of people were agreeing that Leader is involved in inspiring or motivating people to participate in activities. It shows that Leader is involved in inspiring or motivating people to participate in activities.Data shows that $26.7 \%$ people were strongly agreed on the statement that Leader keeps an open mind, majority $50.0 \%$ people were agreed with this, $10.7 \%$ people were disagreed with the statement, $7.3 \%$ people were strongly disagreed, only $5.3 \%$ people were neither agreed, nor disagreed on the statement. It shows that majority of people were agreed on the statement that Leader keeps an open mind. Data shows that Leader keeps an open mind.Data shows that $36.0 \%$ people were strongly agreed on the statement that Leader helps others and feels comfortable in the group, majority $40.7 \%$ people were agreed with this, $9.3 \%$ people were disagreed with the statement, $9.3 \%$ people were strongly disagreed, and only $4.7 \%$ people were neither agreed, nor disagreed on the statement. It shows that majority of people were agreed on the statement that Leader helps others and feels comfortable in the group.

Table 2: Percentage distribution along with mean and standard deviation regarding People perception about leader behavior

\begin{tabular}{|c|c|c|c|c|c|c|c|}
\hline \multirow[t]{2}{*}{$\begin{array}{l}\text { People perception about } \\
\text { leader behavior }\end{array}$} & $\begin{array}{l}\text { Strongly } \\
\text { Agreed }\end{array}$ & Agreed & $\begin{array}{l}\text { Neither } \\
\text { Agreed, Nor } \\
\text { Disagreed }\end{array}$ & Disagreed & $\begin{array}{l}\text { Strongly } \\
\text { Disagreed }\end{array}$ & \multirow[t]{2}{*}{ Mean } & \multirow[t]{2}{*}{ S.D } \\
\hline & \multicolumn{5}{|c|}{ Percentage } & & \\
\hline Leader is very intelligent. & 54.7 & 36.0 & 2.0 & 2.7 & 4.7 & 1.67 & .994 \\
\hline $\begin{array}{l}\text { Leader is a good public } \\
\text { speaker and listener. }\end{array}$ & 39.3 & 46.0 & 1.3 & 11.3 & 2.0 & 1.91 & 1.019 \\
\hline $\begin{array}{l}\text { Leader has a very friendly } \\
\text { personality. }\end{array}$ & 40.0 & 38.0 & 3.3 & 12.7 & 6.0 & 2.20 & 1.274 \\
\hline $\begin{array}{l}\text { Leader is honest and you } \\
\text { could trust him. }\end{array}$ & 31.3 & 22.0 & 4.0 & 25.3 & 17.3 & 3.67 & 1.472 \\
\hline $\begin{array}{l}\text { Leader shows persistence and } \\
\text { determination in achieving } \\
\text { goals. }\end{array}$ & 24.7 & 38.7 & 4.7 & 20.0 & 12.0 & 2.56 & 1.368 \\
\hline $\begin{array}{l}\text { Leader gives very clear } \\
\text { instructions. }\end{array}$ & 35.3 & 38.0 & 6.0 & 9.3 & 11.3 & 2.23 & 1.328 \\
\hline $\begin{array}{l}\text { Leader treats you with } \\
\text { respect. }\end{array}$ & 26.7 & 37.3 & 2.7 & 20.0 & 13.3 & 2.56 & 1.412 \\
\hline $\begin{array}{l}\text { Leader invites you to share in } \\
\text { the decision-making. }\end{array}$ & 32.0 & 44.7 & 4.7 & 12.0 & 6.7 & 2.17 & 1.195 \\
\hline $\begin{array}{l}\text { Leader improves } \\
\text { relationships. }\end{array}$ & 45.3 & 30.7 & 4.0 & 10.0 & 10.0 & 2.09 & 1.341 \\
\hline $\begin{array}{l}\text { I am satisfied with his/her } \\
\text { task about actions and } \\
\text { outcome. }\end{array}$ & 15.3 & 23.3 & 4.7 & 31.3 & 25.3 & 3.28 & 1.452 \\
\hline $\begin{array}{l}\text { Leader has influence on } \\
\text { people behavior. }\end{array}$ & 26.0 & 41.3 & 3.3 & 19.3 & 10.0 & 2.46 & 1.329 \\
\hline $\begin{array}{l}\text { People behavior is usually } \\
\text { complex rather than simple. }\end{array}$ & 49.3 & 41.3 & 1.3 & 5.3 & 2.7 & 1.71 & .938 \\
\hline
\end{tabular}

Data that we get from respondents reflects that $54.7 \%$ respondents were strongly agreed with statement that Leader is very intelligent, majority $36.0 \%$ people were agreed with this, $2.7 \%$ people were disagreed with the statement, while $4.7 \%$ respondents were strongly disagreed that way that Leader is very intelligent, only $2.0 \%$ people were neither agreed, nor disagreed with the statement. It shows that Leader is very intelligent.Value indicators shows that $39.3 \%$ people were strongly agreed with the statement that Leader is a good public speaker and listener, and $46.0 \%$ people were agreed while only $1.3 \%$ respondents were neither agreed, nor disagreed. So it shows that majority of people were agreed that Leader is a good public speaker and listener.Value data shows that $40.0 \%$ people were strongly agreed with the statement that Leader has a very friendly personality, $12.7 \%$ respondents were disagreed with the statement.Data reflects that $31.3 \%$ respondents were strongly agreed that Leader is honest and you could trust him, only $4.0 \%$ people were neither agreed, nor disagreed with the statement. Findings reflect that Leader is honest and you could trust him. Findings shows that $24.7 \%$ respondents were strongly agreed with the statement that Leader shows persistence and determination in 
achieving goals, while a majority $38.7 \%$ of people were agreed with the statement, $20.0 \%$ people were disagreed with the statement, only $12.0 \%$ respondents were strongly disagreed with this, $4.7 \%$ people were neither agreed, nor disagreed on the statement. It shows that majority of people agreed on the statement that Leader shows persistence and determination in achieving goals.

Data shows that majority of people think Leader gives very clear instructions. 35.3\% respondents were strongly agreed Leader gives very clear instructions, $38.0 \%$ people were agreed, while $9.3 \%$ were disagreed with statement, $11.3 \%$ respondents were strongly disagreed; only $6.0 \%$ people are neither agreed, nor disagreed. So above findings show that Leader gives very clear instructions. $26.7 \%$ respondents were strongly agree that Leader treats you with respect, while $20.0 \%$ people were disagreed with the statement. Data of value indicates that $32.0 \%$ respondents were strongly with statement that Leader invites you to share in the decisionmaking, majority $44.7 \%$ people were agreed with this, $12.0 \%$ people were disagreed with the statement.Result of value reflect that $45.3 \%$ respondents were strongly agreed with statement that Leader improves social relationships, majority $30.7 \%$ people were agreed with this, $10.0 \%$ people were disagreed with the statement, while $10.0 \%$ respondents were strongly disagreed.Data shows that $26.0 \%$ respondents were strongly agreed that I am satisfied with his/her task about actions and outcome. On this statement that Leader has influence on people behavior, respondents have different perception like $26.0 \%$ respondents were strongly agreed that Leader has influence on people behavior, while a majority $41.3 \%$ of people were agreed with the statement, $19.3 \%$ people were disagreed with the statement, only $10.0 \%$ respondents were strongly disagreed with this, 3.3\% people were neither agreed, nor disagreed on the statement. Data reflect that Leader has influence on people behavior.On this statement that People behavior is usually complex rather than simple, respondents have different perception like $49.3 \%$ respondents were strongly agreed.

Table 3: Percentage distribution along with mean and standard deviation regarding Leader work for his or her personal benefit

\begin{tabular}{|c|c|c|c|c|c|c|c|}
\hline \multirow[t]{2}{*}{$\begin{array}{l}\text { Leader work for his or her } \\
\text { personal benefit }\end{array}$} & $\begin{array}{l}\text { Strongly } \\
\text { Agreed }\end{array}$ & Agreed & $\begin{array}{l}\text { Neither } \\
\text { Agreed, Nor } \\
\text { Disagreed } \\
\end{array}$ & Disagreed & $\begin{array}{l}\text { Strongly } \\
\text { Disagreed }\end{array}$ & \multirow[t]{2}{*}{ Mean } & \multirow[t]{2}{*}{ S.D } \\
\hline & \multicolumn{5}{|c|}{ Percentage } & & \\
\hline $\begin{array}{l}\text { Leader misleads for her or his } \\
\text { own benefit. }\end{array}$ & 53.3 & 40.7 & 2.0 & 4.0 & 0 & 1.57 & .727 \\
\hline $\begin{array}{l}\text { Leader criticizes on a personal } \\
\text { level rather than criticizing at } \\
\text { work level. }\end{array}$ & 39.3 & 56.0 & 2.7 & 2.0 & 0 & 1.67 & .629 \\
\hline $\begin{array}{l}\text { Leader is dishonest for his or } \\
\text { her benefit. }\end{array}$ & 44.1 & 55.9 & 0 & 0 & 0 & 1.41 & .521 \\
\hline $\begin{array}{l}\text { Leader deliberately provides } \\
\text { false or misleading } \\
\text { information. }\end{array}$ & 47.1 & 50.0 & 0 & 2.9 & 0 & 1.67 & .642 \\
\hline $\begin{array}{l}\text { Leader places blame for her or } \\
\text { his failures. }\end{array}$ & 30.0 & 61.3 & 3.3 & 3.3 & 2.0 & 1.86 & .795 \\
\hline $\begin{array}{l}\text { Leader deliberately makes feel } \\
\text { inferior. }\end{array}$ & 12.7 & 23.3 & 9.3 & 28.0 & 26.7 & 3.33 & 1.42 \\
\hline $\begin{array}{l}\text { Leader threatens in order to get } \\
\text { what she or he wants. }\end{array}$ & 50.7 & 36.0 & 1.3 & 8.7 & 3.3 & 1.78 & 1.07 \\
\hline
\end{tabular}

Table 3 shows that 53.3percent respondents are strongly agreed that leader misleads for her or his own benefit, and 40.7 percent were agreed, $2.0 \%$ respondents were Neither agreed nor disagreed, while $4.0 \%$ respondents were disagreed, $0 \%$ were strongly disagreed with this statement, and It shows that majority of people were strongly agreed on the statement that Leader misleads for her or his own benefit. Indicators shows that about $39.3 \%$ respondents were strongly agreed that Leader criticizes on a personal level rather than criticizing at work level, $56.0 \%$ people were agreed, only $2.7 \%$ people are neither agreed nor disagreed, while $2.0 \%$ were disagreed with statement, $0 \%$ respondents were strongly disagreed, So above findings shows that majority of respondents were agreeing on the statement that Leader criticizes on a personal level rather than criticizing at work level.Data shows that $44.1 \%$ respondents were strongly agreed with statement that Leader is dishonest for his or her personal benefit. Table shows that $30.0 \%$ people were strongly agreed, majority $61.3 \%$ of people were agreed with this statement, $3.3 \%$ people are neither agreed nor disagreed with this statement, $3.3 \%$ people were disagreed on this, $2.0 \%$ respondents were strongly disagreed with that Leader places blame for her or his failures. So above results shows that majority of people were agreed on the statement.Table indicates that 12.7 $\%$ people were strongly agreed with the statement, $26.7 \%$ people were strongly disagreed that Leader deliberately makes feel inferior, So it shows that majority of people were disagreed that Leader deliberately makes feel inferior.Table also indicates that $50.7 \%$ people were strongly agreed with the statement, and $36.0 \%$ people were agreed with this, $1.3 \%$ respondents were neither agreed, nor disagreed while only $8.7 \%$ respondents were disagreed with the statement, $3.3 \%$ people were strongly disagreed that Leader deliberately 
makes feel inferior, So it shows that majority of people were strongly agreed that Leader threatens in order to get what she or he wants.

\section{Hypothesis 1: People perceive that mostly leaders are after their own interest.}

Table 4:Association between Leadership behavior and Leader motivate and solve problems of people.

\begin{tabular}{|c|c|c|c|c|c|}
\hline \multirow{2}{*}{\multicolumn{2}{|c|}{$\begin{array}{l}\text { Leadership } \\
\text { behavior }\end{array}$}} & \multicolumn{3}{|c|}{ Leader motivate and solve problems of people } & \multirow[b]{2}{*}{ Total } \\
\hline & & Low & Medium & High & \\
\hline \multirow{2}{*}{\multicolumn{2}{|c|}{ Low }} & 5 & 2 & 1 & 8 \\
\hline & & $3.3 \%$ & $1.3 \%$ & $.7 \%$ & $5.3 \%$ \\
\hline \multirow{2}{*}{\multicolumn{2}{|c|}{ Medium }} & 8 & 38 & 15 & 61 \\
\hline & & $5.3 \%$ & $25.3 \%$ & $10.0 \%$ & $40.7 \%$ \\
\hline \multirow[t]{4}{*}{ High } & & 4 & 24 & 53 & 81 \\
\hline & & $2.7 \%$ & $16.0 \%$ & $35.3 \%$ & $54.0 \%$ \\
\hline & & 17 & 64 & 69 & 150 \\
\hline & $\%$ of Total & $11.3 \%$ & $42.7 \%$ & $46.0 \%$ & $100.0 \%$ \\
\hline
\end{tabular}

Chi-square $=45.573^{\mathrm{a}} \quad$ d.f. $=4$

Significance $=.000 * * * \quad$ Gamma $=.672$

\section{Discussion:}

Table 4 indicates the relationship between leadership behavior and leaders motivate and solve problems of people. The calculated value and the alternative hypothesis accepted. Present the association between leader behavior and leader motivate and solve problems of people. Leader has a sense of confidence and control and Conform your understanding. Chi-square value shows a highly-significant association between them. Gamma value shows a positive relationship between the variables. The relationship between leadership behavior and leaders motivate and solve problems of people emerged as significant at $.000 * * *$ level supported by high values of Pearson Chi-square, Likelihood ratio, and Linear by Linear association at. The value of gamma is .672, also significant. Low behavioral observed $11.3 \%$ with low 'leader knowledge and information' level, and the high level of 'leaders motivate and solve problems of people' had shown high behavioral $46.0 \%$. The calculated value of the chi-square and the value of gamma also significant; indicating a strong and positive association between leader behavior and leader motivate and solve problems of people.

Hence the hypothesis "People perceive that mostly leader are after their own interest" is accepted.

\section{Conclusion:}

Present research is an attempt to analyze the poor leadership in different sectors and also to investigate the possible causes of this issue of poor leadership. In this research, I investigated People are agreed that Leader Shares information with his subordinate to increase the confidence and listens ideas or advice that contradicts his viewpoints. Leader encourages group members to do quality work and sets standards of performance for group members. Result of the study shows that Leader do not creates co-operative environment and the leader is not able to identify new and creative ways to solve problems and creating an environment where differences of opinion can be voiced. People are not satisfied with leader task, actions and outcome. People behavior is usually complex rather than simple about leader. Results show that Leader is not honest and people could not trust him. Bad supporters as a part of bad leadership, making the point those dishonest leaders usually have dishonest supporters. The findings of the research that leader misleads people and dishonest for her or his own benefit. Leader threatens people in order to get what he wants. Some of the reasons for bad leadership are lack of knowledge about leadership, immoral habits and selfishness. It is reality that leader become great because of their knowledge One of the biggest problems of facing poor leadership is that so many of people are prepared to tolerate or even support those who are not fit to lead.

\section{References}

[1]. Anthony, T. (1995) Darker Shades of Blue: A Case Study of Failed Leadership. Bass, B. (1990) Leadership in Different Countries and Cultures

[2]. Bryman, A. (1993) Charisma and leadership in organizations

[3]. English, F.W. (1992). Educational administration: The human science.

[4]. Hersey, P., \& Blanchard, K.H. (1969) Management of organizational behavior: Utilizing human resources. New Jersey: Prentice Hall.

[5]. Morakul (2001) and Jansen (2000) Leadership style, employee motivation and commitment: Empirical evidence from a consolidated retail bank operating in a depressed economy

[6]. Squires, G. (2001) Management as a professional discipline: Journal of Management Studies.34 (4), p. 11.

[7]. Stefani, L., Weiss, M., and Strickland, J. (1999) The effect of leader outcomes on influence, attributions, and perceptions of charisma 